\title{
PENGARUH BUDAYA ORGANISASI DAN DUKUNGAN ORGANISASI TERHADAP OCB DIMEDIASI OLEH KOMITMEN ORGANISASIONAL
}

\author{
Putu Enda Wira Saputra ${ }^{1}$ \\ I Wayan Gede Supartha ${ }^{2}$ \\ ${ }^{1,2}$ Fakultas Ekonomi dan Bisnis Universitas Udayana (Unud), Bali, Indonesia \\ email: endhawira@gmail.com
}

\begin{abstract}
ABSTRAK
Keberhasilan suatu organisasi bukan hanya ditentukan oleh sumber daya alam melainkan sumber daya manusia (SDM) tergantung pada kualitas dan perilaku-perilaku yang timbul didalam didalam organisasi. Perilaku yang diharapkan adalah perilaku yang dapat meningkatkan kualitas organisasi yaitu Organizational Citizenship Behavior(OCB). Tujuan dalam penelitian adalah untuk menjelaskan dan menganalisis pengaruh budaya organisasi dan dukungan organisasi terhadap OCB dimediasi oleh komitmen organisasional. Penelitian ini dilakukan di Dinas Tenaga Kerja dan ESDM Provinsi Bali sebanyak 100 PNS dengan menggunakan metode sampel non probability sampling, dikumpulkan melalui kuesioner menggunakan teknik analisis statistik deskriptif, analisis jalur dan uji sobel. Hasil penelitian menunjukkan bahwa Budaya Organisasi, Dukungan Organisasi dan Komitmen Organisasi masing-masing berpengaruh positif signifikan terhadap Organizational Citizenship Behavior (OCB) serta adanya peran mediasi Komitmen Organisasional terhadap OCB yang memperkuat hubungan antara budaya organisasi dan dukungan organisasi. Dinas Tenaga Kerja dan ESDM harus memperhatikan budaya organisasi yang ada dilingkungan organisasi serta dukungan organisasi yang harus ditingkatkan sehingga perilaku-perilaku OCB dapat meningkat untuk kualitas pegawai yang lebih baik.
\end{abstract}

Kata Kunci : budaya organisasi; dukungan organisasi; komitmen organiasional;

Organizational Citizenship Behavior (OCB).

\begin{abstract}
The success of an organization is not only determined by natural resources but human resources (HR) depending on the quality and behaviors that arise within the organization. Expected behavior is behavior that can improve the quality of the organization, namely Organizational Citizenship Behavior (OCB). The purpose of the study was to explain and analyze the influence of organizational culture and organizational support for $O C B$ mediated by organizational commitment. This research was conducted in the Department of Manpower and Energy and Mineral Resources of Bali Province as many as 100 civil servants using non probability sampling methods, collected through questionnaires using descriptive statistical analysis techniques, path analysis and sobel test. The results showed that Organizational Culture, Organizational Support and Organizational Commitment each had a significant positive effect on Organizational Citizenship Behavior (OCB) as well as the mediating role of Organizational Commitment to $O C B$ that strengthened the relationship between organizational culture and organizational support. The Department of Manpower and Energy and Mineral Resources must pay attention to the existing organizational culture within the organization and organizational support that must be improved so that $O C B$ behaviors can be improved for better quality employees.
\end{abstract}

Keywords: organizational culture; organizational support; organizational commitment; Organizational Citizenship Behavior (OCB) 


\section{PENDAHULUAN}

Perusahaan ketika didirikan tentunya memiliki tujuan yang ingin dicapai. Sumber daya manusia atau SDM menjadi salah satu pendukung untuk tercapainya tujuan organisasi. SDM menjadi asset yang penting bagi perusahaan. Perusahaan yang dapat melakukan pengelolaan yang baik terhadap SDM yang dimilikinya cenderung memiliki perusahaan dengan SDM yang berkinerja baik. SDM dengan kinerja yang baik akan meningkatkan kinerja perusahaan. Perusahaan yang memiliki SDM yang berkinerja baik akan membantu perusahaan dalam mencapai tujuan yang telah ditetapkan oleh perusahaan.

Setiap pegawai tentunya memiliki tugas dan tanggung jawab mereka masingmasing. Diluar tanggung jawab dan tugas yang dimiliki tersebut pegawai dapat mengerjakan tugas lain dengan ikhlas dan hal tersebut dapat membantu perusahaan dalam mencapai tujuan yang ditetapkan. Perilaku tersebut disebut dengan perilaku peran ekstra atau organizational citizenship behavior (OCB). Ketika pegawai perusahaan berperilaku OCB maka akan berdampak pada meningkatnya produktivitas perusahaan (Harper, 2015).

Penelitian ini dilakukan di Dinas Tenaga Kerja dan ESDM Provinsi Bali. Berdasarkan hasil prariset dengan menggunakan wawancara awal terhadap 10 orang pegawai di bidang bina hubungan industrial dan pengawasan ketenagakerjaan, bidang perluasan kesempatan kerja dan transmigrasi bahwa terdapat beberapa masalah di Dinas Tenaga Kerja dan ESDM Provinsi Bali yaitu dapat dilihat dari sikap pegawai yang hanya mengerjakan tugas dan tanggung jawab sendiri serta tidak memiliki keinginan untuk membantu rekan kerja yang memiliki beban kerja yang berlebihan dan sering dalam jam kerja pegawai tidak berada diruangan. Serta masih tingginya ego atau ketidakpedulian dari setiap pegawai masing-masing bidang dengan bidang yang lain dalam berkoordinasi mengenai pekerjaan sehingga berpengaruh terhadap kinerja dari pegawai tersebut. Masih terdapat pegawai yang hanya datang absen namun tidak ada diruangan tanpa ada kejelasan pegawai kemana. Bahwa terdapat beberapa pegawai yang pulang mendahului dari jam kantor yang sudah ditetapkan oleh organisasi. perilaku ini timbul karena komitmen yang dimiliki pegawai masih kurang maksimal sehingga menyebabkan rendahnya perilaku OCB pegawai dalam organiasai. Hal ini disebabkan budaya organiasi yang masih terlalu lemah yang membuat pegawai menjadikan perilaku diatas tersebut menjadi suatu kebiasan dan tidak memiliki inisiatif dan agresif dalam meningkatkan kinerjanya.

Organizational citizenship behavior (OCB) adalah perilaku dari pegawai perushaan yang secara sukarela dan iklas membantu sesama rekan kerjanya. Dilihat dari penelitian Masoud, Abdolmajid, \& Farhad (2014) yang menyatakan bahwa OCB adalah perilaku secara sekarela dimana bukan bagian dari tugas yang sudah ditetapkan dan tidak dihargai secara langsung. Menurut Abdul (2014) OCB merupakan tindakan perilaku individu yang bebas, yang tidak secara langsung diakui oleh system pemberian penghargaan dalam fungsi efektif suatu organisasi.

Stanley (2013) menyatakan bahwa OCB ditandai dengan usaha dalam bentuk apapun yang dilakuan berdasarkan kebijaksanaan pegawai yang memberikan manfaat bagi organisasi tanpa mengharapkan imbalan apapun. Rendahnya OCB dapat dipengaruhi oleh beberapa faktor yang dapat menyebabkan rendahnya 
perilaku OCB yaitu komitmen organisasional merupakan identifikasi rasa, keterlibatan, dan loyalitas yang ditampakkan oleh pegawai terhadap organisasi yang menjadi tempatnya untuk mengabdi dan bekerja. Rendahnya komitmen organisasional, mencerminkan kurangnya tanggung jawab pegawai dalam menjalankan tugasnya. Mempersoalkan komitmen sama dengan mempersoalkan tanggung jawab. Pentingnya membangun OCB dalam lingkungan kerja, tidak lepas dari bagaimana komitmen yang ada dalam diri pegawai untuk memajukan organisasinya. Komitmen yang tinggi menjadikan individu peduli dengan nasib organisasi dan berusaha menjadikan organisasi ke arah yang lebih baik, sehingga dengan adanya komitmen yang tinggi akan mempengaruhi pegawai untuk melakukan perilaku OCB

Dalam meningkatkan komitmen pegawai dalam bekerja dibutuhkan budaya organisasi yang mampu memberikan dampak positif bagi OCB dan komitmen organisasional disuatu organisasi atau perusahaan. Menurut Xiaoming \& Junchen (2012) memecahkan permasalahan yang terdapat diperusahaan baik masalah internal maupun masalah eksternal yang kemudian membentuk pola yang secara terus-menerus diterapkan oleh organisasi disebut dengan budaya organisasi.

Dukungan organisasi juga dapat memberikan dampak yang cukup mempengaruhi OCB dengan dukungan organisasi yang rendah akan mempengaruhi pandangan pegawai terhadap organisasinya. Jika pegawai memiliki pandangan yang buruk terhadap organisasinya akan berdampak terhadap komitmen dari pegawai itu sendiri. Dukungan organisasi merupakan persepsi pegawai terhadap organisasi mengenai sejauh mana organisasi memberikan dukungan kepada pegawai (Rhoades \& Eisenberger, 2002). Dukungan organisasi adalah suatu keyakinan global yang menggambarkan mengenai sejauh mana organisasi menghargai kontribusi pegawai dan peduli tentang kesejahteraan pegawai (Eisenberger \& Huntington, 1986).

Dalam meningkatkan kinerja pegawai maka tingkat komitmen yang dimiliki pegawai itu penting hingga dengan komitmen pegawai yang tinggi perilaku OCB akan semakit kuat dalam menunjang kemajuan suatu organisasi serta budaya organisasi yang diterapkan mampu memberikan dampak yang baik terhadap OCB didalam organisasi serta dukungan organisasi yang tetap memberikan motivasi dalam meningkatkan perilaku OCB pegawai.

Teori yang melandasi penelitian ini adalah Social Exchange Theory. Bila seseorang memberi bantuan, ada kewajiban tersirat untuk membayar kembali bantuan tersebut. Robins \& Judge (2008) menyatakan definisi dari OCB adalah ketika pegawai melakukan suatu pekerjaan diluar pekerjaan dan tanggung jawab utamanya dimana perilaku dari pegawai tersebut dapat berdampak pada kemajuan perushaan. Stanley (2013) dalam mendefinisikan OCB yaitu perilaku tulus ikhlas pegawai dalam melakukan suatu pekerjaan untuk kemajuan perusahan.

Robins \& Judge (2008) mendefinisikan bahwa Komitmen Organisasional adalah suatu keadaan dimana seorang pegawai memihak organisasi tertentu serta tujuan-tujuan dan keinginannya untuk mempertahankan keanggotaan dalam organisasi yang di pihaknya tersebut. Stiti et al. (2013) memiliki pernyataan mengenai pentingnya peran komitmen organisasional dalam mempengaruhi 
bagimana keadaan perusahaan ketika menghadapi masalah-masalah yang tidak sederhana yang terjadi pada perushaan (Robins \& Judge, 2008).

Penelitian yang dilakukan oleh Wibawa \& Putra (2018) dan Khan \& Rashid (2015) dengan judul penelitian pengaruh budaya organisasi terhadap komitmen organisasional dimediasi oleh kepuasan kerja mendapat hasil bahwa budaya organisasi berpengaruh positif terhadap komitmen organisasional. Hasil penelitian yang dilakukan oleh Alfiana \& Puspasari (2015) mendapat hasil bahwa ada pengaruh yang positif antara budaya organisasi terhadap komitmen organisasi karyawan PT. Sinar Sosro Surabaya. Hasil yang sama juga diperoleh oleh Permatasari \& Supartha (2017) bahwa budaya organisasi memiliki pengaruh yang signifikan terhadap komitmen organisasional karyawan. Lanjar et al. (2017) mendapatkan hasil yang sama bahwa budaya organisasi berpengaruh positif terhadap komitmen organisasional.

$\mathrm{H}_{1}$ : Budaya Organisasi Berpengaruh Positif dan signifikan Terhadap Komitmen

Organisasional.

Dukungan organisasi terhadap pegawai yang bekerja untuk organisasi tersebut dianggap penting karena dukungan yang diberikan perusahaan adakan berdampak baik pada perusahaan. Dukungan yang diberikan perusahaan juga akan membentuk rasa cinta karyawan terhadap perusahaan tempatnya bekerja. Karyawan yang merasa diberi dukungan oleh perusahaan cenderung memiliki mindset untuk memajukan perusahaannya. Rasa cinta dan keinginan akan kemajuan perusahaan merupakan salah satu bentuk loyalitas dari keryawan terhadap perusahaan. Loyalitas ini kemudian akan membentuk komitmen yang ditetapkan oleh karyawan. Karyawan yang berkomitmen terhadap perusahaannya memiliki keinginan dalam memajukan dan membantu perusahaan dalam mencapai tujuan yang telah ditetapkan oleh perusahaan. Penelitian yang dilakukan oleh Fahrizal \& Utama (2017), Santoso \& Mangundjaya (2018), Putra et al. (2016), Vitria (2017), Utomo, \& Wijaya (2017) mendapatkan hasil adanya pengaruh positif antara dukungan organisasi pada komitmen organisasional karyawan.

$\mathrm{H}_{2}$ : Dukungan Organisasi berpengaruh positif dan signifikan terhadap Komitmen

Organisasional

Menurut Penelitan Xiaoming \& Junchen (2012) mendapat hasil budaya organisasi yang positif signifikan terhadap OCB. Penelitian yang dilakukan Arifin (2015) menemukan bahwa Budaya Organisasi berpengaruh positif terhadap Organizational Citienship Behavior. Menurut penelitian Cahyono dkk. (2016) serta Wijaya dan Yuniawan (2017) menemukan adanya hubungan positif antara budaya organisasi pada OCB. Menurut muliani dkk (2015) hasil dari penelitiannya diketahui terdapat pengaruh yang signifikan antara budaya organisasi terhadap organizational citizenship behavior (OCB). Penelitian dari Erna setyawati (2012) juga menyatakan bahwa budaya organisasi memberikan pengaruh signifikan dan positif terhadap OCB pegawai PT. PLN (Persero) Area Pelayanan dan Jaringan (APJ) Purwoketo.

$\mathrm{H}_{3}$ : Budaya organisasi Berpengaruh Positif dan signifikan terhadap organizational citizenship behavior (OCB).

Organizational citizenship behavior (OCB) adalah perilaku dari pegawai perushaan yang secara sukarela dan iklas membantu sesama rekan kerjanya. Dilihat 
dari penelitian Masoud et al. (2014) yang menyatakan bahwa OCB adalah perilaku secara sekarela dimana bukan bagian dari tugas yang sudah ditetapkan dan tidak dihargai secara langsung. Menurut Abdul (2014) OCB merupakan tindakan perilaku individu yang bebas, yang tidak secara langsung diakui oleh system pemberian penghargaan dalam fungsi efektif suatu organisasi. Dukungan organisasi juga dapat memberikan dampak yang cukup mempengaruhi OCB dengan dukungan organisasi yang rendah akan mempengaruhi pandangan pegawai terhadap organisasinya. Jika pegawai memiliki pandangan yang buruk terhadap organisasinya akan berdampak terhadap komitmen dari pegawai itu sendiri. Dukungan organisasi merupakan persepsi pegawai terhadap organisasi mengenai sejauh mana organisasi memberikan dukungan kepada pegawai (Rhoades \& Eisenberger, 2002).

Peneltian yang dilakukan oleh Miao (2011), Ali et al. (2015), Novira (2015), dan Sutanto (2018) menemukan adanya pengaruh positif antara variabel dukungan organisasi pada OCB.

$\mathrm{H}_{4}$ : Dukungan Organisasi berpengaruh positif dan signifikan terhadap

Organizational Citizenship Behavior

Pada penelitian sebelumnya yang dilakukan oleh Gautam et al.,(2004), hen dan Francesco (2003), Rahmawati (2013), Sani (2013), Devi dan Adnyani (2015). Ratnaningsih (2013),dan Rini dkk. (2013) mendapatkan hasil bahwa Komitmen Organisasional memiliki pengaruh positif signifikan terhadap OCB

$\mathrm{H}_{5}$ : Komitmen Organisasional berpengaruh positif dan signifikan terhadap organizational citizenship behavior (OCB).

Wijaya dan Yuniawan (2017) dalam penelitiannya menemukan budaya organisasi serta dukungan organisasi memiliki hubungan yang positif pada OCB dengan variabel komitmen organisasional sebagai variabel intervening. Sedangkan menurut Akhtar (dalam Sanhaji, 2016) menyatakan bahwa budaya organisasi dapat membantu meningkatkan komitmen para karyawan.

$\mathrm{H}_{6}$ : Budaya Organisasi terhadap Organizational Citizenship Behavior berpengaruh positif dengan Komitmen Organisasional sebagai variabel mediasi

Penelitian yang diakukan oleh Ardi (2015) menunjukkan bahwa komitmen organisasional berperan dalam memediasi dukungan organisasi terhadap OCB. Hasil yang didapat oleh Khan \& Rashid (2015) mendapatkan hasil komitmen organisasi adalah faktor penengah untuk mempengaruhi karyawan dalam suatu organisasi untuk menunjukkan perilaku proaktif ini untuk meningkatkan berfungsinya organisasi secara efektif yang artinya komitmen berperan memediasi terhadap OCB. Peneltian yang dilakukan di china oleh Wang (2014) mendapat hasil bahwa komimen organisasi mampu memediasi dukungan organisai untuk meningkatkan OCB karyawan.

$\mathrm{H}_{7}$ : Dukungan organiasi terhadap Organizational Citizenship Behavior berpengaruh positif dengan komitmen organisasional sebagai variabel mediasi

\section{METODE PENELITIAN}

Pada penelitian ini, peneliti mengambil lokasi penelitian di Dinas Tenaga Kerja dan ESDM Provinsi Bali yang beralamat di Jalan Raya Puputan-Niti Mandala Renon Denpasar Bali, Indonesia. Alasan yang melatarbelakangi peneliti 
melakukan di Dinas Tenaga Kerja dan ESDM Provinsi Bali karena peneliti melihat ada permasalahan yang menyangkut OCB pada organisasi ini. Pada penelitian ini obyek yang digunakan adalah pegawai negeri sipil ( bukan pegawai kontrak) yang telah berdinas pada instansi tersebut untuk mendapatkan hubungan antara Budaya Organisasi dan Dukungan organisasi terhadap Organizational citizenship behavior (OCB) dimediasi oleh Komitmen Organisasional.

Sesuai dengan judul penelitian ini, peneliti memaparkan hubungan antara Budaya Organisasi dan Dukungan organisasi terhadap Organizational citizenship behavior (OCB) dimediasi oleh komitmen organisasional. Dengan uraian sebagai berikut, yaitu Variabel endogen adalah Organizational citizenship behavior (OCB) (Y). Variabel eksogen adalah Budaya organisasi dan dukungan organisasi (X). Variabel mediasi adalah Komitmen Organisasional (M). Organ (2003) menyatakan bahwa ada 5 (lima) dimensi pada OCB yaitu Altruism, Conscientiousness, Courtessy, Sportsmanship, Civiv Virtue

Berdasarkan pendapat para ahli, mengatakan bahwa budaya organisasi merupakan suatu sistem berbagi arti yang dilakukan para anggota yang membedakan suatu organisasi dari organisasi lain. Menurut Kurniawati dan Sariyathi (2015), indikator budaya organisasi sebagai berikut: inovasi memperhitungkan resiko, memberi perhatian pada setiap masalah secara detail., berorientasi terhadap hasil yang akan dicapai, berorietasi kepada semua kepentingan anggota, semangat dalam bekerja. Berdasarkan beberapa ahli, menyatakan bahwa Komitmen Organisasional dipandang sebagai suatu orientasi nilai terhadap organisasi yang menunjukkan pemikiran individu dan mengutamakan pekerjaan dan organisasinya. Menurut Allen dan Meyer (1990) dalam Darmawan (2013:148).

Indikator-indikator untuk mengukur variabel dukungan organisasi menurut (Eisenberger \& Huntington, 1986) yaitu : organisasi menghargai kontribusi pegawai, organisasi sudah cukup memberi pengakuan kerja ekstra yang sudah dilakukan pegawai, organisasi akan menanggapi dengan baik jika pegawai memiliki keluhan, organisasi akan memberikan bantuan bila pegawai mengahadapi kesulitan, organisasi peduli dengan kesejahteraan pegawai., organisasi akan lebih perhatian apabila pegawai bekerja dengan baik, pegawai organisasi akan menunjukkan prestasi pegawai kepada pegawai lain. Populasi dalam penelitian ini adalah seluruh PNS yang bekerja di Dinas Tenaga Kerja dan ESDM Provinsi Bali yang berjumlah 106 orang pegawai PNS.

Pengambilan sampel dalam penelitian ini menggunakan teknik non probability sampling.Teknik sampling yang digunakan adalah teknik sampel jenuh yaitu sebanyak 100 orang PNS (tidak termasuk pimpinan atau atasan) di Dinas Tenaga Kerja dan ESDM Provinsi Bali. Jenis data yang digunakan dalam penelitian ini adalah sebagai berikut: Data kuantitatif adalah data berupa angka-angka. Data kuantitatif dalam penelitian ini adalah bobot skor atas jawaban responden pada pengisian kuesioner yang dikuantitatifkan. Data kualitatif yang digunakan dalam penelitian ini adalah sejarah perusahaan, struktur organisasi dan aktivitas pada Dinas Tenaga Kerja dan ESDM Provinsi Bali.

Data primer dalam penelitian ini adalah data penyebaran kuesioner kepada pegawai Dinas Tenaga Kerja dan ESDM Provinsi Bali. Data sekunder adalah data yang 
dalam bentuk jadi, yang diperoleh dari pihak lain yang telah mengumpulkan data tersebut seperti jurnal, internet dan buku

\section{Tabel 1.}

Jumlah Pegawai Negeri Sipil Dinas Tenaga Kerja Provinsi Bali

\begin{tabular}{|c|c|c|c|}
\hline No & Bidang/Sekretariat & Jumlah & Pegawai \\
\hline 1 & Pelatihan dan Produktivitas & & 14 \\
\hline 2 & Bina Hubungan Industrial dan Pengawas Ketenagakerjaan & & 34 \\
\hline 3 & Perluasan Kesempatan Kerja dan Transmigrasi & & 15 \\
\hline 4 & Energi dan Sumber Daya Mineral & & 17 \\
\hline 5 & Sub Bagian Umum dan Kepegawaian & & 11 \\
\hline 6 & Sub Bagian Keuangan & & 6 \\
\hline \multirow[t]{2}{*}{7} & Sub Bagian Perencanaan Program, Evaluasi dan Pelaporan & & 3 \\
\hline & Jumlah & & 100 \\
\hline
\end{tabular}

Sumber : Dinas Tenaga Kerja dan Energi Sumber Daya Mineral Provinsi Bali, 2019

Metode pengumpulan data dalam penelitian ini menggunakan beberapa metode, yaitu sebagai berikut Kuesioner merupakan teknik pengumpulan data dengan memberi seperangkat pernyataan. Masing-masing pernyataan dalam kuesioner akan diukur menggunakan skala Likert, yaitu sangat setuju diberi skor 5, setuju diberi skor 4, cukup setuju diberi skor 3, tidak setuju diberi skor 2, sangat tidak setuju diberi skor 1 . Prariset yang digunakan adalah wawancara yang tidak terstruktur. Prariset Observasi berarti peneliti mengadakan pengamatan langsung pada Dinas Tenaga Kerja dan ESDM Provinsi Bali untuk dapat mengetahui kondisi serta permasalahan yang akan diteliti di dalam perusahaan tersebut.

\section{HASIL DAN PEMBAHASAN}

Tabel 2.

Karakteristik Responden

\begin{tabular}{|c|c|c|c|c|}
\hline No & Karakteristik & Klasifikasi & $\begin{array}{c}\text { Jumlah } \\
\text { Responden } \\
\text { (orang) }\end{array}$ & $\begin{array}{c}\text { Presentase } \\
\text { Responden } \\
(\%)\end{array}$ \\
\hline \multirow{4}{*}{1} & \multirow{4}{*}{ Umur } & 28 - 35 Tahun & 18 & 18.0 \\
\hline & & 36 - 43 Tahun & 29 & 29.0 \\
\hline & & 44 - 51 Tahun & 27 & 27.0 \\
\hline & & $>51$ Tahun & 26 & 26.0 \\
\hline \multirow{4}{*}{2} & \multicolumn{2}{|c|}{ Jumlah } & 100 & 100 \\
\hline & & Laki - Laki & 63 & 63.0 \\
\hline & Jenis Kelamin & Perempuan & 37 & 37.0 \\
\hline & \multicolumn{2}{|c|}{ Jumlah } & 100 & 100 \\
\hline \multirow{4}{*}{3} & \multirow{4}{*}{ Pendidikan } & SMA & 2 & 2.0 \\
\hline & & Diploma & 15 & 15.0 \\
\hline & & $\mathrm{S} 1$ & 45 & 45.0 \\
\hline & & $\mathrm{S} 2$ & 38 & 38.0 \\
\hline \multirow{7}{*}{4} & \multirow{7}{*}{ Lama Bekerja } & & 100 & 100 \\
\hline & & 4 - 10 Tahun & 23 & 23.0 \\
\hline & & 11 - 17 Tahun & 33 & 33.0 \\
\hline & & 18 - 24 Tahun & 14 & 14.0 \\
\hline & & 25 - 31 Tahun & 14 & 14.0 \\
\hline & & $>31$ Tahun & 16 & 16.0 \\
\hline & & Jumlah & 100 & 100 \\
\hline
\end{tabular}

Sumber : Data diolah, 2019 
Pada Tabel 2. diatas jika dilihat dari umur, 36 - 40 Tahun adalah umur yang paling mendominasi diantara yang lainnya dengan jumlah 29 orang atau 29\%. Dalam penelitian ini responden jika dilihat dari jenis kelamin, sebagian besar responden berjenis kelamin laki - laki yakni 63 orang atau 63\%. Dalam penelitian ini responden jika dilihat dari pendidikan terakhir, pegawai didominasi tamatan S1 yakni 45 orang atau $45 \%$. Jika dilihat dari karakteristik responden pada bagian lama bekerja, responden di dominasi oleh lama bekerja 11 - 17 tahun yakni 33 orang atau $33 \%$.

Tabel 3.

Rekapitulasi Hasil Uji Reliabilitas Instrumen Penelitian

\begin{tabular}{cccc}
\hline No. & Variabel & Cronbach's Alpha & Keterangan \\
\hline 1 & Budaya Organisasi $\left(\mathrm{X}_{1}\right)$ & 0,908 & Reliabel \\
2 & Dukungan Organisasi $\left(\mathrm{X}_{2}\right)$ & 0,844 & Reliabel \\
3 & Komitmen Organisasional $(\mathrm{M})$ & 0,882 & Reliabel \\
4 & Organizational Citizenship & 0,897 & Reliabel \\
\hline
\end{tabular}

Sumber : Data diolah, 2019

Setelah dilakukan uji reliabilitas didpatkan hasil yaitu nilai koefisien Cronbach's Alpha untuk seluruh instrumen penelitian bernilai lebih dari 0,60. Dengan nilai yang melebihi 0,60 maka instumen yang digunakan yaitu kuesioner serta butir-butir pertanyaan yang diajukan kepada responden menghasilkan data yang reliabel.

Uji normalitas bertujuan untuk menguji apakah data yang digunakan dalam model regresi berdistribusi normal atau tidak. Penelitian ini menggunakan uji normalitas Kolmogorov-Smirnov. Koefesien Asymp.sig.(2-tailed) lebih besar dari 0,05 .

Tabel 4.

Hasil Uji Normalitas Model Struktur 1

\begin{tabular}{lc}
\hline & Unstandardized Residual \\
\hline $\mathrm{N}$ & 100 \\
Kolmogorov-Smirnov & 0,085 \\
Asymp Sig (2-tailed) & 0,074 \\
\hline Sumber : Data diolah, 2019
\end{tabular}

Sumber : Data diolah, 2019

Setelah dilakukan uji normalitas untuk struktur 1 didpatkan hasil yaitu nilai Asymp Sig (2-tailed) untuk data pada penelitian ini bernilai lebih dari 0,005 yaitu 0,074. Data yang didapatkan dari responden memiliki distribusi normal.

Tabel 5.

\begin{tabular}{|c|c|}
\hline \multicolumn{2}{|c|}{ Hasil Uji Normalitas Model Struktur 2} \\
\hline & Unstandardized Residual \\
\hline $\mathrm{N}$ & 100 \\
\hline Kolmogorov-Smirnov & 0,066 \\
\hline Asymp Sig (2-tailed) & 0,200 \\
\hline
\end{tabular}

Sumber : Data diolah, 2019 
Setelah dilakukan uji normalitas untuk struktur 2 didpatkan hasil yaitu nilai Asymp Sig (2-tailed) untuk data pada penelitian ini bernilai lebih dari 0,005 yaitu 0,200 . Data yang didapatkan dari responden memiliki distribusi normal.

Uji Multikolineritas bertujuan untuk menemukan apakah ada kolerasi antara variabel bebas di dalam model regresi. Regresi yang baik seharusnya tidak terjadi kolerasi diantara variabel bebas (Fahrizal \& Utama, 2017). Nilai tolerance dan nilai Variance Inflation Factor (VIF) dapat digunakan untuk mengkolerasi ada atau tidaknya kolerasi antara sesama variabel bebas. Pengujian multikolineritas digunakan untuk mengetahui apakah terdapat multikolineritas atau tidak dengan melihat tolerance value lebih dari 10\% dan Value Inflation Factor (VIF) kurang dari 10.

Tabel 6.

Hasil Uji Multikoleniaritas

\begin{tabular}{llcc}
\hline \multicolumn{1}{c}{ Persamaan Struktur } & \multicolumn{1}{c}{ Variabel } & Tolerance & VIF \\
\hline $\mathrm{M}=\beta_{1} \mathrm{X}_{1}+\beta_{2} \mathrm{X}_{2}+\mathrm{e}_{1}$ & Budaya Organisasi $\left(\mathrm{X}_{1}\right)$ & 0,347 & 2,878 \\
& Dukungan Organisasi $\left(\mathrm{X}_{2}\right)$ & 0,347 & 2,878 \\
$\mathrm{Y}=\beta_{3} \mathrm{X}_{1}+\beta_{4} \mathrm{X}_{2}+\beta_{5} \mathrm{M}+\mathrm{e}_{2}$ & Budaya Organisasi $\left(\mathrm{X}_{1}\right)$ & 0,300 & 3,335 \\
& Dukungan Organisasi $\left(\mathrm{X}_{2}\right)$ & 0,286 & 3,492 \\
& Komitmen Organisasional $(\mathrm{M})$ & 0,342 & 2,926 \\
\hline
\end{tabular}

Sumber : Data diolah, 2019

Setelah dilakukan uji multikolinearitas didpatkan hasil yaitu nilai tolerance untuk data pada penelitian ini bernilai lebih dari $10 \%$ dan didpatkan hasil yaitu nilai VIF untuk data pada penelitian ini bernilai lebih kecil dari 10. Hasil ini menunjukkan tidak ditemukannya masalah multikolinearitas dalam data yang digunakan.

Uji Heteroskedastisitas digunakan untuk menguji apakah dalam suatu model regresi ketidaksamaan varian dari residual satu pengamatan ke pengamatan lain. Regresi yang baik tidak mengandung gejala heteroskedastisitas jika semua variabel bebas tidak berpengaruh signifikan terhadap nilai yang absolute residual atau nilai signifikansinya diatas 0,05 akan memperlihatkan bahwa model yang dibuat tidak mengandung gejala heteroskedasistisitas.

Setelah dilakukan uji heteroskedastisitas untuk struktur 1 didapatkan hasil yaitu nilai signifikansi untuk variabel yang diujikan bernilai lebih tinggi dari nilai 0,05 . Dari hasil ini disimpulkan bahwa variabel budaya organisasi dan dukungan organisasi pada struktur 1 terbebas dari masalah heteroskedastisitas.

Setelah dilakukan uji heteroskedastisitas untuk struktur 2 didapatkan hasil yaitu nilai signifikansi untuk variabel yang diujikan bernilai lebih tinggi dari nilai 0,05. Dari hasil ini disimpulkan bahwa variabel pada struktur 2 terbebas dari gejala heteroskedastisitas.

$\mathrm{M}=\beta_{1} \mathrm{X}_{1}+\beta_{2} \mathrm{X}_{2}+\mathrm{e}_{1}$

$\mathrm{M}=0,395 \mathrm{X}_{1}+0,458 \mathrm{X}_{2}+0,134$

Dari hasil uji jalur model 1 didapatkan hasil bahwa budaya organisasi dan dukungan organisasi berpengaruh positif pada komitmen organisasi. Pengaruh positif ini dapat dilihat dari nilai koefisien dari variabel $\mathrm{X}_{1}$ dan $\mathrm{X}_{2}$. Diketahui juga dari hasil uji sobel model 1 yaitu nilai signifikansi uji t yang kurang dari 0,05. 
Nilai $\mathrm{R}^{2}$ diketahui sebesar 0,658 . Nilai $\mathrm{R}^{2}$ ini memiliki arti yaitu sebesar budaya organisasi dan dukungan organisasi mempengaruhi variasi komitmen organisasional sebanya $65,8 \%$ sedangkan sisanya sebanyak $34,2 \%$ dipengaruhi oleh variabel alin yang tidak digunakan pada model penelitian ini.

Tabel 7.

Hasil Uji Heteroskedastisitas Model Struktur 1

\begin{tabular}{|c|c|c|c|c|c|c|}
\hline \multicolumn{7}{|c|}{ Coefficients $^{\mathrm{a}}$} \\
\hline \multirow{2}{*}{\multicolumn{2}{|c|}{ Model }} & \multicolumn{2}{|c|}{$\begin{array}{l}\text { Unstandardized } \\
\text { Coefficients }\end{array}$} & \multirow{2}{*}{$\begin{array}{c}\text { Standardized } \\
\text { Coefficients } \\
\text { Beta }\end{array}$} & \multirow[t]{2}{*}{$\mathrm{t}$} & \multirow[t]{2}{*}{ Sig. } \\
\hline & & B & $\begin{array}{l}\text { Std. } \\
\text { Error }\end{array}$ & & & \\
\hline \multirow[t]{3}{*}{1} & (Constant) & 5.424 & 1.407 & & 3.854 & .000 \\
\hline & $\begin{array}{l}\text { Budaya } \\
\text { Organisasi }\end{array}$ & -.060 & .109 & -.093 & -.552 & .582 \\
\hline & $\begin{array}{l}\text { Dukungan } \\
\text { Organisasi }\end{array}$ & -.064 & .082 & -.132 & -.782 & .436 \\
\hline
\end{tabular}

Sumber : Data diolah, 2019

Tabel 8.

Hasil Uji Heteroskedastisitas Model Struktur 2

\begin{tabular}{|c|c|c|c|c|c|c|}
\hline \multicolumn{7}{|c|}{ Coefficients $^{\mathrm{a}}$} \\
\hline \multicolumn{2}{|c|}{ Model } & \multicolumn{2}{|c|}{$\begin{array}{l}\text { Unstandardized } \\
\text { Coefficients }\end{array}$} & \multirow{2}{*}{$\begin{array}{c}\text { Standardized } \\
\text { Coefficients } \\
\text { Beta }\end{array}$} & \multirow[t]{2}{*}{$\mathbf{T}$} & \multirow[t]{2}{*}{ Sig. } \\
\hline & & B & Std. Error & & & \\
\hline 1 & (Constant) & -.101 & 1.351 & & -.075 & .940 \\
\hline & $\begin{array}{l}\text { Budaya } \\
\text { Organisasi }\end{array}$ & .098 & .111 & .158 & .887 & .377 \\
\hline & $\begin{array}{l}\text { Dukungan } \\
\text { Organisasi }\end{array}$ & .152 & .085 & .326 & 1.785 & .077 \\
\hline & $\begin{array}{l}\text { Komitmen } \\
\text { Organisasional }\end{array}$ & -.101 & .059 & -.289 & -1.729 & .087 \\
\hline
\end{tabular}

Sumber : Data diolah, 2019

$$
\begin{gathered}
\mathrm{Y}=\beta_{3} \mathrm{X}_{1}+\beta_{4} \mathrm{X}_{2}+\beta_{5} \mathrm{Y}_{1}+\mathrm{e}_{2} \ldots \ldots \ldots \ldots \ldots \ldots \ldots \ldots \\
\mathrm{Y}=0,273 \mathrm{X}_{1}+0,372 \mathrm{X}_{2}+0,322 \mathrm{M}+0,101
\end{gathered}
$$

Nilai koefisien regresi variabel budaya organisasi, dukungan organisasi dan komitmen organisasional bernilai positif dengan nilai signifikansi uji t kurang dari 0,05 . Hal ini menunjukkan bahwa variabel budaya organisasi, dukungan organisasi dan komitmen organisasional memiliki pengaruh positif yang signifikan terhadap 
variabel organizational citizenship behavior (OCB). Besarnya pengaruh variabel bebas terhadap variabel terikat yang ditunjukkan oleh nilai determinasi total ( $\mathrm{R}$ Square) sebesar 0,802 mempunyai arti bahwa sebesar $80,2 \%$ variabel organizational citizenship behavior (OCB). dipengaruhi oleh variasi budaya organisasi, dukungan organisasi dan komitmen organisasional, sedangkan sisanya sebesar 19,8\% dijelaskan oleh faktor lain yang tidak dimasukkan ke dalam model.

Tabel 9.

Hasil Analisis Jalur Model 1

\begin{tabular}{lrrrrr}
\hline \multicolumn{1}{c}{ Variabel } & \multicolumn{2}{c}{$\begin{array}{c}\text { Unstandardized } \\
\text { Coefficients }\end{array}$} & $\begin{array}{c}\text { Standardized } \\
\text { Coefficients } \\
\text { Beta }\end{array}$ & $\begin{array}{c}\mathbf{t} \\
\text { hitung }\end{array}$ & Sig. uji t \\
& B & Std. Error & & & \\
\hline & 4.902 & 2.286 & & 2.145 & .034 \\
Budaya Organisasi & .698 & .178 & .395 & 3.924 & .000 \\
$\quad\left(\mathrm{X}_{1}\right)$ & & & & & \\
Dukungan Organisasi & .609 & .134 & .458 & 4.548 & .000 \\
$\quad\left(\mathrm{X}_{2}\right)$ & & & & & \\
R Square & 0,658 & & & & \\
F Statistik & 93,433 & & & & \\
Signifikansi Uji F & 0,000 & & & &
\end{tabular}

Tabel 10.

Hasil Analisis Jalur Model 2

\begin{tabular}{|c|c|c|c|c|c|}
\hline \multirow[t]{2}{*}{ Variabel } & \multicolumn{2}{|c|}{$\begin{array}{c}\text { Unstandardized } \\
\text { Coefficients }\end{array}$} & \multirow{2}{*}{$\begin{array}{c}\text { Standardized } \\
\text { Coefficients } \\
\text { Beta }\end{array}$} & \multirow[t]{2}{*}{ t hitung } & \multirow[t]{2}{*}{ Sig. uji t } \\
\hline & B & Std. Error & & & \\
\hline (Constant) & 23.336 & 2.337 & & 9.983 & .000 \\
\hline $\begin{array}{l}\text { Budaya Organisasi } \\
\left(\mathrm{X}_{1}\right)\end{array}$ & .629 & .191 & .273 & 3.290 & .001 \\
\hline $\begin{array}{l}\text { Dukungan Organisasi } \\
\left(\mathrm{X}_{2}\right)\end{array}$ & .647 & .147 & .372 & 4.389 & .000 \\
\hline $\begin{array}{l}\text { Komitmen } \\
\text { Organisasional (M) }\end{array}$ & .421 & .101 & .322 & 4.146 & .000 \\
\hline R Square & 0,802 & & & & \\
\hline F Statistik & 129,653 & & & & \\
\hline Signifikansi Uji F & 0,000 & & & & \\
\hline
\end{tabular}

Berdasarkan perhitungan pengaruh error (Pei), didapatkan hasil pengaruh error $\left(\mathrm{Pe}_{1}\right)$ sebesar 0,585 dan pengaruh error $\left(\mathrm{Pe}_{2}\right)$ sebesar 0,445 . Nilai determinasi total sebesar 0,936 mempunyai arti bahwa sebesar 93,6\% variabel organizational citizenship behavior dipengaruhi oleh variabel budaya organisasi, dukungan organisasi dan komitmen organisasional, sedangkan sisanya sebesar 6,4\% djelaskan oleh faktor lain yang tidak dimasukkan ke dalam model.

Hasil analisis untuk hipotesis pertama yaitu $\mathrm{H}_{1}$ diterima dan $\mathrm{H}_{0}$ ditolak. Diterimanya $\mathrm{H}_{1}$ dapat dilihat dari nilai signifikansi yang kurang dari 0,05 yaitu 0,000 . Hal ini berarti ditemukannya hubungan positif antara budaya organisasi pada 
komitmen organisasional. Hubungan positif ini dapat dilihat dari nilai koefisien beta yang didapat dari hasil analisis yaitu 0,395 .

Hal tersebut menunjukan bahwa semakin baik kualitas budaya organisasi maka akan semakin baik juga kualitas komitmen organisasional pegawai. Hal tersebut sesuai dengan hasil penelitian yang dilakukan oleh Wibawa \& Putra (2018) yaitu budaya organisasi berpengaruh positif terhadap komitmen organisasional. Selain itu, hasil senada juga didapat dari penelitian yang dilakukan oleh oleh Alfiana \& Puspasari (2015) mendapat hasil bahwa ada pengaruh yang positif antara budaya organisasi terhadap komitmen organisasi. Hasil yang sama juga diperoleh oleh Permatasari \& Supartha (2017) bahwa budaya organisasi memiliki pengaruh yang signifikan terhadap komitmen organisasional karyawan. Lanjar, Hamid, \& Muksan (2017) juga mendapatkan hasil yang sama.

Hasil analisis untuk hipotesis kedua yaitu $\mathrm{H}_{2}$ diterima dan $\mathrm{H}_{0}$ ditolak. Diterimanya $\mathrm{H}_{2}$ dapat dilihat dari nilai signifikansi yang kurang dari 0,05 yaitu 0,000 . Hal ini berarti ditemukannya hubungan positif antara dukungan organisasi pada komitmen organisasional. Hubungan positif ini dapat dilihat dari nilai koefisien beta yang didapat dari hasil analisis yaitu 0,458.

Berdasarkan pemaparan di atas dapat dinyatakan bahwa semakin baik kualitas dukungan organisasi perusahaan terhadap karyawan maka akan semakin baik pula kualitas komitmen organisasional karyawan. hal tersebut sesuai dengan hasil penelitaian yang dilakukan oleh Penelitian yang dilakukan oleh Fahrizal \& Utama (2017), Santoso \& Mangundjaya (2018), Putra et al. (2016), Vitria (2017), Utomo, \& Wijaya (2017) mendapatkan hasil adanya pengaruh positif antara dukungan organisasi pada komitmen organisasional karyawan. Dukungan organisasi terhadap pegawai yang bekerja untuk organisasi tersebut dianggap penting karena dukungan yang diberikan perusahaan adakan berdampak baik pada perusahaan. Dukungan yang diberikan perusahaan juga akan membentuk rasa cinta karyawan terhadap perusahaan tempatnya bekerja. Karyawan yang merasa diberi dukungan oleh perusahaan cenderung memiliki mindset untuk memajukan perusahaannya. Rasa cinta dan keinginan akan kemajuan perusahaan merupakan salah satu bentuk loyalitas dari keryawan terhadap perusahaan. Loyalitas ini kemudian akan membentuk komitmen yang ditetapkan oleh karyawan. Karyawan yang berkomitmen terhadap perusahaannya memiliki keinginan dalam memajukan dan membantu perusahaan dalam mencapai tujuan yang telah ditetapkan oleh perusahaan.

Hasil analisis untuk hipotesis ketiga yaitu $\mathrm{H}_{3}$ diterima dan $\mathrm{H}_{0}$ ditolak. Diterimanya $\mathrm{H}_{3}$ dapat dilihat dari nilai signifikansi yang kurang dari 0,05 yaitu 0,001 . Hal ini berarti ditemukannya hubungan positif antara budaya organisasi pada OCB. Hubungan positif ini dapat dilihat dari nilai koefisien beta yang didapat dari hasil analisis yaitu 0,273 .

Beranjak dari hasil analisis di atas maka dapat dinyatakan bahwa kualitas budaya organisasi memberikan andil terhadap kualitas organizational citizenship behavior (OCB). Semakin baik kualitas budaya organisasi maka akan semakin baik pula organizational citizenship behavior (OCB). Pemaparan tersebut sesuai dengan hasil penelitian yang dilakukan oleh Arifin (2015) menemukan bahwa Budaya Organisasi berpengaruh positif terhadap Organizational Citienship Behavior. 
Menurut penelitian Cahyono dkk. (2016) menemukan adanya hubungan positif antara budaya organisasi pada OCB. Menurut muliani dkk (2015) hasil dari penelitiannya diketahui terdapat pengaruh yang signifikan antara budaya organisasi terhadap organizational citizenship behavior (OCB). Penelitian dari Erna setyawati (2012) juga menyatakan bahwa budaya organisasi memberikan pengaruh signifikan dan positif terhadap OCB pegawai. Penelitian Wijaya dan Yuniawan (2017) juga menyatakan bahwa budaya organisasi berpengaruh positif dan signifikan terhadap organizational citizenship behavior. Dengan demikian dapat dinyatakan bahwa Budaya organisasi Berpengaruh Positif dan signifikan terhadap organizational citizenship behavior (OCB).

Hasil analisis untuk hipotesis keempat yaitu $\mathrm{H}_{4}$ diterima dan $\mathrm{H}_{0}$ ditolak. Diterimanya $\mathrm{H}_{4}$ dapat dilihat dari nilai signifikansi yang kurang dari 0,05 yaitu 0,000 . Hal ini berarti ditemukannya hubungan positif antara dukungan organisasi pada OCB. Hubungan positif ini dapat dilihat dari nilai koefisien beta yang didapat dari hasil analisis yaitu 0,372 .

Sesuai hasil analisis di atas dapat dinyatakan bahwa kualitas dukungan organisasi memberikan andil terhadap kualitas Organizational Citizenship Behavior (OCB). Semakin baik kualitas dukungan organisasi maka akan semakin baik pula kualitas Organizational Citizenship Behavior (OCB). Hal tersebut senada dengan hasil penelitian yang dilakukan oleh Novira (2015) mendapat hasil bahwa dukungan organisasi memberikan pengaruh terhadap OCB. Hal ini sesuai dengan penelitian yang dilakukan oleh Puspitasari (2014) bahwa dukungan organisasi memiliki pengaruh positif dan signifikan terhadap OCB. Peneltian yang dilakukan oleh Ali et al.,(2015) mendapat hasil bahwa dukungan organisasi memiliki pengaruh positif terhadap perilaku OCB karyawan. Penelitian yang dilakukan oleh Sutanto (2018) menyatakan bahwa dukungan organisasi memiliki pengaruh yang positif untuk meningkatkan OCB karyawan. Denga demikian dapat dinytakan bahwa Dukungan Organisasi berpengaruh positif dan signifikan terhadap Organizational Citizenship Behavior.

Hasil analisis untuk hipotesis kelima yaitu $\mathrm{H}_{5}$ diterima dan $\mathrm{H}_{0}$ ditolak. Diterimanya $\mathrm{H}_{5}$ dapat dilihat dari nilai signifikansi yang kurang dari 0,05 yaitu 0,000 . Hal ini berarti ditemukannya hubungan positif antara komitmen organisasional pada OCB. Hubungan positif ini dapat dilihat dari nilai koefisien beta yang didapat dari hasil analisis yaitu 0,322 .

Sesuai hasil analisis yang diperoleh maka dapat dinyatakan bahwa kualitas komitmen organisasional memberikan pengaruh pada kualitas Organizational Citizenship Behavior (OCB). Hal tersebut memberikan makna bahwa Senakin baik kualitas komitmen organisasional maka akan semakin baik pula kualitas Organizational Citizenship Behavior (OCB). Hasil tersebut senada dengan penelitian yang dilakukan oleh Rahmawati (2013) ditemukan bahwa Komitmen Organisasional memberikan pengaruh yang positif terhadap OCB. Penelitian yang dilakukan oleh Sani (2013) yaitu Komitmen Organisasional berpengaruh positif terhadap OCB. Selain itu, Ratnaningsih (2013) dalam penelitiannya menemukan bahwa komitmen memberikan pengaruh yang positif terhadap OCB. 
Tabel 11.

Pengaruh variabel Budaya Organisasi $\left(\mathrm{X}_{1}\right)$ terhadap Organizational Citizenship Behavior (Y) dengan Komitmen Organisasional (M)

\begin{tabular}{cccc}
\hline Pengaruh Variabel & Pengaruh Langsung & Pengaruh Tidak Langsung & $\begin{array}{c}\text { Pengaruh } \\
\text { Total }\end{array}$ \\
\hline $\mathrm{X}_{1} \rightarrow \mathrm{M}$ & 0,395 & - & 0,395 \\
$\mathrm{X}_{1} \rightarrow \mathrm{Y}$ & 0,273 & 0,127 & 0,400 \\
$\mathrm{M} \rightarrow \mathrm{Y}$ & 0,322 & - & 0,322 \\
\hline Sumber $:$ Data diolah, 2019 & &
\end{tabular}

$\mathrm{X}_{1}$ memiliki pengaruh langsung terhadap $\mathrm{M}$ sebesar $0,395 . \mathrm{X}_{1}$ memiliki pengaruh pada $Y$ dengan di mediasi $M$ sebesar 0,273. $M$ memiliki pengaruh langsung pada $\mathrm{Y}$ sebesar 0,322 . Pengaruh tidak langsung yang dimiliki oleh $\mathrm{X}_{1}$ pada $\mathrm{Y}$ dengan dimediasi $\mathrm{M}$ adalah sebesar 0,127 . Total dari pengaruh langsung dan tidak langsung antara variabel $\mathrm{X}_{1}$ pada $\mathrm{Y}$ dengan dimediasi $\mathrm{M}$ addalah 0,400 . Disimpulkan bahwa pengaruh $\mathrm{X}_{1}$ pada $\mathrm{Y}$ lebih kuat ketika dimediasi oleh variabel $\mathrm{M}$ dilihat dari total pengaruh langsung dan tidak langsung dari ketiga variabel tersebut memiliki nilai yang lebih besar daripada tanpa dimediasi oleh variabel $\mathrm{M}$.

Tabel 12.

Pengaruh variabel Dukungan Organisasi $\left(\mathrm{X}_{2}\right)$ terhadap Organizational Citizenship Behavior (Y) dengan Komitmen Organisasi (M)

\begin{tabular}{cccc}
\hline Pengaruh Variabel & Pengaruh Langsung & Pengaruh Tidak Langsung & $\begin{array}{c}\text { Pengaruh } \\
\text { Total }\end{array}$ \\
\hline $\mathrm{X}_{2} \rightarrow \mathrm{M}$ & 0,458 & - & 0,458 \\
$\mathrm{X}_{2} \rightarrow \mathrm{Y}$ & 0,372 & 0,147 & 0,519 \\
$\mathrm{M} \rightarrow \mathrm{Y}$ & 0,322 & - & 0,322 \\
\hline
\end{tabular}

Sumber : Data diolah, 2019

$\mathrm{X}_{2}$ memiliki pengaruh langsung terhadap $\mathrm{M}$ sebesar $0,458 \mathrm{X}_{2}$ memiliki pengaruh pada $\mathrm{Y}$ dengan di mediasi $\mathrm{M}$ sebesar 0,372 . $\mathrm{M}$ memiliki pengaruh langsung pada $Y$ sebesar 0,322. Pengaruh tidak langsung yang dimiliki oleh $\mathrm{X}_{1}$ pada $\mathrm{Y}$ dengan dimediasi $\mathrm{M}$ adalah sebesar 0,147. Total dari pengaruh langsung dan tidak langsung antara variabel $\mathrm{X}_{2}$ pada $\mathrm{Y}$ dengan dimediasi $\mathrm{M}$ addalah 0,519 . Disimpulkan bahwa pengaruh $\mathrm{X}_{2}$ pada $\mathrm{Y}$ lebih kuat ketika dimediasi oleh variabel $\mathrm{M}$ dilihat dari total pengaruh langsung dan tidak langsung dari ketiga variabel tersebut memiliki nilai yang lebih besar daripada tanpa dimediasi oleh variabel $\mathrm{M}$.

Setelah mengetahui pengaruh hubungan tiap variabel, dilakukan uji sobel untuk mengetahui t hitung yang kemudian mencerminkan arah hubungan dari variabel-variabel yang digunakan. Pengujian yang pertama adalah untuk mengetahui t hitung dari pengaruh $\mathrm{X}_{1}$ pada $\mathrm{Y}_{2}$ melalui $\mathrm{M}$. Berdasarkan rumus uji sobel yang digunakan didapatkan t hitung untuk pengaruh $\mathrm{X}_{1}$ pada $\mathrm{Y}_{2}$ melalui $\mathrm{M}$ adalah 2,826. Nilai ini lebih besar dari 1,96. Hasil ini memiliki arti bahwa pengaruh $\mathrm{X}_{1}$ pada $\mathrm{Y}_{2}$ memiliki pengaruh yang positif dengan $\mathrm{M}$. 
Setelah mengetahui pengaruh hubungan tiap variabel, dilakukan uji sobel untuk mengetahui $\mathrm{t}$ hitung yang kemudian mencerminkan arah hubungan dari variabel-variabel yang digunakan. Pengujian yang pertama adalah untuk mengetahui t hitung dari pengaruh $\mathrm{X}_{2}$ pada $\mathrm{Y}$ melalui $\mathrm{M}$. Berdasarkan rumus uji sobel yang digunakan didapatkan $t$ hitung untuk pengaruh $\mathrm{X}_{2}$ pada $\mathrm{Y}$ melalui $\mathrm{M}$ adalah 3,276. Nilai ini lebih besar dari 1,96. Hasil ini memiliki arti bahwa pengaruh $\mathrm{X}_{2}$ pada $\mathrm{Y}$ memiliki pengaruh yang positif dengan $\mathrm{M}$.

Berdasarkan hasil analisis didapat $t$ hitung sebesar 2,826 $>1,96$. Artinya Budaya Organisasi terhadap Organizational Citizenship Behavior berpengaruh positif dengan Komitmen Organisasional sebagai variabel mediasi. Hasil tersebut memberikan makna bahwa kualitas budaya organisasi memengaruhi kualitas komitmen organisasi. Sedangkan kualitas komitmen organisasi memberikan pengaruh terhadap Organizational Citizenship Behavior (OCB).

Hal tersebut senada dengan hasil penelitian yang dilakukan oleh Wijaya dan Yuniawan (2017) mendapatkan hasil bahwa budaya organisasi dan dukungan organisasi terhadap ocb dengan komitmen rganisasional sebagai variabel intervening berpengaruh positif dan signifikan. Sedangkan menurut Akhtar (dalam Sanhaji, 2016) menyatakan bahwa budaya organisasi dapat membantu meningkatkan komitmen para karyawan. Penelitian Khan \& Rashid (2015) menghasilkan sebuah kesimpulan bahwa komitmen organisasional merupakan variabel mediasi yang baik untuk mengetahui hubungan antara budaya organisasi, gaya kepemimpinan dan keadilan organisasi terhadap OCB. Dengan demikian dapat dinytakan bahwa Budaya Organisasi berpengaruh positif terhadap Organizational Citizenship Behavior dengan Komitmen Organisasional sebagai variabel mediasi.

Berdasarkan hasil analisis didapat t hitung sebesar 3,276 > 1,96. Artinya Dukungan organiasi terhadap Organizational Citizenship Behavior berpengaruh positif dengan komitmen organisasional sebagai variabel mediasi. Hasil tersebut memberikan makna bahwa kualitas Dukungan Organisasi memengaruhi kualitas komitmen organisasi. Sedangkan kualitas komitmen organisasi memberikan pengaruh terhadap Organizational Citizenship Behavior (OCB).

Hasil tersebut sesuai dengan hasil peenelitian Ardi (2015) dengan hasil penelitian bahwa komitmen organisasional berperan dalam memediasi dukungan organisasi terhadap OCB. Wang (2014) mendapat hasil bahwa komimen organisasi mampu memediasi dukungan organisai untuk meningkatkan OCB karyawan. Penelitian yang dilakukan Nafrizal (2015) menyatakan bahwa komitmen organisasi memediasi dukungan organisasi terhadap OCB. Hasil penelitian yang dilakukan oleh Marthing dan Sandroto (2018) mendapat hasil bahwa komitmen memiliki pengaruh yang positif dalam memediasi dukungan organisasi terhadap OCB karyawan. Dengan demikian dapat dinyatakan bahwa Dukungan organiasi berpengaruh positif terhadap Organizational Citizenship Behavior dengan komitmen organisasional sebagai variabel mediasi.

OCB adalah suatu perilaku secara tulus iklas dan sukarela dimana bukan bagian dari perkerjaan yang sudah ditetapkan dan tidak dihargai secara langsung. OCB adalah suatu perilaku yang positif individu sebagai anggota organisasi dalam bentuk kesedian secara sadar dan sukarela untuk membantu pekerjaan rekan dan 
berkontribusi pada organisasi yang mendukung berfungsi organisasi secara efektif. Kualityas OCB yang baik akan membuat perusahaan lebih optimal dalam mencapai tujuan perusahaan. Hal tersebut melatarbelakangi alasan agar perusahaan hendaknya fokus pada usaha dalam meningkatkan OCB karyawan.

Budaya organisasi berpengaruh positif dan signifikan terhadap komitmen organisasional. Hal tersebut berimplikasi pada tindakan yang hendaknya diambil oleh pihak manajemen dalam rangka meningkatkan komitmen organisasional. Berdasarkan asumsi tersebut untuk meningkatkan kualitas komitmen organisasional, pihak manajemen dapat mempertimbangkan budaya organisasi sebagai salah satu faktor yang perlu dioptimalkan. Dukungan Organisasi berpengaruh positif dan signifikan terhadap Komitmen Organisasional. Hal tersebut berimplikasi pada regulasi yang hendaknya dibuat oleh pihak manajemen dalam rangka meningkatkan komitmen organisasional. Berdasarkan asumsi tersebut untuk meningkatkan kualitas komitmen organisasional, pihak manajemen dapat mempertimbangkan Dukungan Organisasi sebagai aspek yang dapat dimaksimalkan.

Budaya organisasi Berpengaruh Positif dan signifikan terhadap organizational citizenship behavior (OCB). Hal tersebut berimplikasi pada penekanan budaya sikap positif yang hendaknya dibuat oleh pihak manajemen dalam rangka meningkatkan organizational citizenship behavior (OCB). Berdasarkan asumsi tersebut untuk meningkatkan kualitas organizational citizenship behavior (OCB), pihak manajemen dapat mempertimbangkan Budaya organisasi sebagai aspek yang dapat dimaksimalkan melalui penerapan sikap-sikap positif saat bekerja.

Dukungan Organisasi berpengaruh positif dan signifikan terhadap Organizational Citizenship Behavior. Hasil tersebut memberikan implikasi pada kebijakan pihak manajemen dalam rangka meningkatkan Organizational Citizenship Behavior karyawan. hal tersebut dapat dilakukan dengan membuat kebijakan yang pro terhadap karyawan. Dukungan organisasi terhadap pegawai yang bekerja untuk organisasi tersebut dianggap penting karena dukungan yang diberikan perusahaan adakan berdampak baik pada perusahaan. Dukungan yang diberikan perusahaan juga akan membentuk rasa cinta karyawan terhadap perusahaan tempatnya bekerja. Karyawan yang merasa diberi dukungan oleh perusahaan cenderung memiliki mindset untuk memajukan perusahaannya. Rasa cinta dan keinginan akan kemajuan perusahaan merupakan salah satu bentuk loyalitas dari keryawan terhadap perusahaan. Loyalitas ini kemudian akan membentuk komitmen yang ditetapkan oleh karyawan. Karyawan yang berkomitmen terhadap perusahaannya memiliki keinginan dalam memajukan dan membantu perusahaan dalam mencapai tujuan yang telah ditetapkan oleh perusahaan.

Komitmen Organisasional berpengaruh positif dan signifikan terhadap organizational citizenship behavior (OCB). Pemaparan tersebut memberikan implikasi bahwa manajemen perusahaan perlu menetapkan regulasi yang dapat memberikan jaminan rasa aman terhadap karyawan sehingga organizational citizenship behavior (OCB) optimal. komitmen organisasional merupakan identifikasi rasa, keterlibatan, dan loyalitas yang ditampakkan oleh pegawai 
terhadap organisasi yang menjadi tempatnya untuk mengabdi dan bekerja. Rendahnya komitmen organisasional, mencerminkan kurangnya tanggung jawab pegawai dalam menjalankan tugasnya. Mempersoalkan komitmen sama dengan mempersoalkan tanggung jawab. Pentingnya membangun OCB dalam lingkungan kerja, tidak lepas dari bagaimana komitmen yang ada dalam diri pegawai untuk memajukan organisasinya. Komitmen yang tinggi menjadikan individu peduli dengan nasib organisasi dan berusaha menjadikan organisasi ke arah yang lebih baik, sehingga dengan adanya komitmen yang tinggi akan mempengaruhi pegawai untuk melakukan perilaku OCB

Budaya Organisasi berpengaruh positif terhadap Organizational Citizenship Behavior dengan Komitmen Organisasional sebagai variabel mediasi. Hasil tersebut memberikan implikasi bahwa pihak menajemen perusahaan terutama stake holder perusahaan secara bersama-sama perlu membuat inovasi baru agar budaya organisasi serta komitmen organisasional berkualitas baik. Hal gtersebut akan berpengaruh terhadap kualitas organizational citizenship behavior (OCB). Dalam meningkatkan komitmen pegawai dalam bekerja dibutuhkan budaya organisasi yang mampu memberikan dampak positif bagi OCB dan komitmen organisasional disuatu organisasi atau perusahaan. Menurut Xiaoming \& Junchen (2012) memecahkan permasalahan yang terdapat diperusahaan baik masalah internal maupun masalah eksternal yang kemudian membentuk pola yang secara terusmenerus diterapkan oleh organisasi disebut dengan budaya organisasi. Dalam meningkatkan kinerja pegawai maka tingkat komitmen yang dimiliki pegawai itu penting hingga dengan komitmen pegawai yang tinggi perilaku OCB akan semakit kuat dalam menunjang kemajuan suatu organisasi serta budaya organisasi yang diterapkan mampu memberikan dampak yang baik terhadap OCB didalam organisasi serta dukungan organisasi yang tetap memberikan motivasi dalam meningkatkan perilaku OCB pegawai.

Dukungan organiasi berpengaruh positif terhadap Organizational Citizenship Behavior dengan komitmen organisasional sebagai variabel mediasi. Hasil tersebut memberikan implikasi bahwa pihak menajemen perusahaan terutama stake holder perusahaan secara bersama-sama perlu membuat regulasi baru agar kualitas Dukungan organiasi serta komitmen organisasional meningkat. Hal tersebut akan berpengaruh terhadap kualitas organizational citizenship behavior (OCB).

Faktor-faktor yang memengaruhi OCB dalam penelitian ini hanya terdiri dari 3 variabel yaitu budaya organisasi, dukungan organisasi, dengan komitmen organisasional sebagai mediasi sedangkan masih terdapat faktor lain yang berpeluang memberikan pengaruh dalam penelitian. Dengan demikian perlu dilakukan replikasi penelitian dengan menambahkan variabel lain yang berpeluang memiliki pengaruh terhadap kinerja karyawan serta merekontruksi kerangka berpikir agar lebih mengambarkan keadaan sebenarnya baik dengan variabel yang memediasi maupun memoderasi.

Penggunaan kuisioner memberikan dampak negatif yaitu data yang didapat berpeluang tidak sesuai dengan keadaan yang sebenarnya. Hal tersebut terjadi karena responden hanya memberikan respon sesuai butir yang disediakan tanpa berkesempatan memberikan tanggapan sesuai dengan keadaan yang dialami 
responden. Dengan demikian perlu ditambahkan kegiatan observasi dan wawancara dalam mengumpulkan data tambahan untuk melakukan triangulasi.

Penggunaan sample dengan jumlah terbatas yaitu sebanyak 100 orang memberikan pengaruh terhadap akurasi hasil penelitian. Hal tersebut akan mempengaruhi generalisasi hasil terhadap populasi keseluruhan.

\section{SIMPULAN}

Budaya organisasi berpengaruh positif dan signifikan terhadap komitmen organisasi. Hal ini menunjukan bahwa jika budaya organisasi semakin meningkat maka akan meningkatkan pula komitmen organisasional pada Dinas Tenaga Kerja dan ESDM Provinasi Bali. Dukungan organisasi berpengaruh positif dan signifikan terhadap komitmen organisasi. Hal ini menunjukan bahwa jika dukungan organisasi semakin meningkat maka akan meningkatkan pula komitmen organisasi pada Dinas Tenaga Kerja dan ESDM Provinasi Bali.

Budaya organisasi berpengaruh positif dan signifikan terhadap organizational citizenship behavior. Hal ini menunjukan bahwa jika budaya organisasi semakin meningkat maka akan meningkatkan pula organizational citizenship behavior pada Dinas Tenaga Kerja dan ESDM Provinasi Bali. Dukungan organisasi berpengaruh positif dan signifikan terhadap Organizational citizenship behavior. Hal ini menunjukan bahwa jika dukungan organisasi semakin meningkat maka akan meningkatkan pula Organizational citizenship behavior pada Dinas Tenaga Kerja dan ESDM Provinsi Bali. Komitmen organisasi berpengaruh positif dan signifikan terhadap organizational citizenship behavior. Hal ini menunjukan bahwa jika komitmen organisasi semakin meningkat maka akan meningkatkan pula organizational citizenship behavior pada Dinas Tenaga Kerja dan ESDM Provinsi Bali.

Komitmen Organisasi mampu memediasi pengaruh Budaya Organisasi terhadap Organizational citizenship behavior. Hal ini menunjukan bahwa Budaya Organisasi memberikan dampak yang signifikan terhadap Organizational citizenship behavior pada Dinas Tenaga Kerja dan ESDM Provinsi Bali jika di mediasi oleh Komitmen Organisasi, yang berarti bahwa pengaruh Budaya Organisasi terhadap Organizational citizenship behavior pada Dinas Tenaga Kerja dan ESDM Provinsi Bali akan diperkuat dengan adannya Komitmen Organisasi.

Komitmen Organisasi mampu memediasi pengaruh Dukungan Organisasi terhadap Organizational citizenship behavior. Hal ini menunjukan bahwa Dukungan Organisasi memberikan dampak yang signifikan terhadap Organizational citizenship behavior jika di mediasi oleh Komitmen Organisasi, yang berarti bahwa pengaruh Dukungan Organisasi terhadap Organizational citizenship behavior pada Dinas Tenaga Kerja dan ESDM Provinsi Bali akan diperkuat dengan adannya Komitmen Organisasi.

\section{REFERENSI}

Abdul, R. F. H. (2014). Perceptions of Organizational Justice as a Predictor of Organizational Citizenship Behavior: An Empirical study at School is Sri Lanka. European Journal of Business and Management., 6(12), 124-130. 
Alfiana, Z., \& Puspasari, M. D. (2015). Pengaruh Budaya Organisasi Terhadap Komitmen Organisasi Pada Karyawan PT. Sinar Sosro Surabaya. Jurnal Administrasi Perkantoran, 3(1), 1-19.

Arifin, H. M. (2015). The Influence of Competence, Motivation, and Organizational Culture to High School Teacher Job Satisfaction and Performance. International Education Studies., 8(1), 38-45.

Eisenberger, R., \& Huntington. (1986). "Perceived Organizational Support." J. Ournal of Applied Psychology, 71, 500-507.

Fahrizal, \& Utama, M. (2017). Pengaruh Persepsi Dukungan Organisasi Terhadap Komitmen Organisasional Dan Turnover Intention Karyawan Hotel Kajane Mua Ubud. E-Jurnal Manajemen Unud, 6(10), 5405-5431.

Harper, P. J. (2015). Exploring Forms of Organizational Citizenship Behaviors (OCB): Antecedents and Outcame. Jounal of Management and Marketing Research, 18, 1-16.

Khan, S. K., \& Rashid, M. Z. (2015). "The Mediating Effect of Organizational Commitment in the Organizational Culture, Leadership and Organizational Justice Relationship with Organizational Citizenship Behavior: A Study of Academicians in Private Higher Learning Institutions in Malaysia". International Journal of Business and Social Science, 3(8), 83-91.

Lanjar, F. A., Hamid, D., \& Muksan, M. D. (2017). Pengaruh Budaya Organisasi Terhadap Komitmen Organisasionaldan Kinerja Karyawan (Studi Pada Karyawan Pabrik Gula Kremboong). Jurnal Administrasi Bisnis, 41(1), 1016.

Masoud, P., Abdolmajid, F., \& Farhad, G. (2014). Explaining The Relationship Between Organizational Climate, Organizational commitment and Organizational Citienship Behavior Among Employees pf Khuzestan Gas Compan. Indian Journal of Fundamental and Applied Life Sciences., 4(3), 282-290.

Permatasari, K. C., \& Supartha., W. G. (2017). Pengaruh kepemimpinan Transformasional, Budaya Organisasi, Dan Keadilan Organisasi Terhadap Komitmen Organisasional Pada Cv.Megah Food Trading. E-Jurnal Manajemen Unud, 6(8), 4127-4155.

Putra, I. D. P. G. W., Sintaasih, D., \& Putra, M. S. (2016). pengaruh dukungan organisasional terhadap kepuasan kerja dan komitmen organisasional (studi pada karyawan outsourcing depo arsip PT X). E-Jurnal Ekonomi Dan Bisnis Universitas Udayana., 5(10), 3531-3560. 
Rhoades, L., \& Eisenberger, R. (2002). "Perceived Organizational Support: A Review of the Literature." Journal of Applied Psychology, 87(4), 698-714.

Robins, S. P., \& Judge, T. A. (2008). Organizational Behavior. US: Prentice Hall.

Santoso, A. R., \& Mangundjaya, W. L. . (2018). Pengaruh Persepsi Dukungan Organisasi Terhadap Komitmen Afektif Untuk Berubah Studi Kasus Pada Kementerian PUPR Yang Sedang Mengalami Perubahan Reformasi Birokrasi. Jurnal Infrastruktur, 4(1), 1-53.

Stanley, S. (2013). Kepemimpinan Transformasional dan Organizational Citizenship Behavior dampaknya terhadap Kinerja Pegawai KPKNL Provinsi Sulawesi Utara. Jurnal EMBA, 1(3), 356-365.

Stiti, A. E., Raharjo, K., \& Hamid, D. (2013). The Effect Of Empewwerment to The Oranizational Commitment and The Job Satisfaction Of The Employees Of The national Electricity Company (Ltd). Asian Tansactions On Basic \& Applied Science, 3(4), 2221-4291.

Vitria, A. (2017). Pengaruh Persepsi Dukungan Organisai Dan Pemberdayaan Kerja Terhadap Komitmen Organisasional (Studi Pada Karyawan Bagian Produksi PDAM Bandarmasih Banjarmasin). Jurnal Kominikasi, Bisnis Dan Manajemen, 4(2), 18-29.

Wibawa, I. W. S., \& Putra, M. S. (2018). Pengaruh Budaya Organisasi Terhadap Komitmen Organisasionaldimediasi Kepuasan Kerja (Studi Pada PT. Bening Badung-Bali). E-Jurnal Manajemen Unud., 7(6), 3017-3058.

Xiaoming, C., \& Junchen, X. (2012). A Literature Review on Organizational Culture and Corporate Performance. International Journal of Business Administration., 3(2), 29-37. 